\title{
O I 23 To overdose or underdose? The question of Kaletra in children in the UK/Irish Collaborative HIV Paediatric Study (CHIPS)
}

\author{
AS Walker*1, KL Boyd ${ }^{1}$, K Doerholt ${ }^{2}$, H Lyall ${ }^{3}$, E Menson ${ }^{4}$, K Butler ${ }^{5}$, \\ P Tookey ${ }^{6}$, A Riordan ${ }^{7}$, D Shingadia ${ }^{8}$, A Judd ${ }^{1}$, G Tudor-Williams ${ }^{3}$ and \\ DM Gibb $^{1}$
}

Address: ${ }^{1}$ MRC Clinical Trials Unit, London, UK, ${ }^{2}$ Bristol Royal Hospital for Children, Bristol, UK, ${ }^{3}$ St Mary's Hospital, London, UK, ${ }^{4}$ Evelina Children's Hospital, London, UK, ${ }^{5}$ Our Lady's Hospital for Sick Children, Dublin, Ireland, ${ }^{6}$ Institute of Child Health, London, UK, ${ }^{7}$ Royal Liverpool Children's NHS Trust, Liverpool, UK and ${ }^{8}$ Great Ormond Street Hospital for Sick Children, London, UK

* Corresponding author

from Ninth International Congress on Drug Therapy in HIV Infection

Glasgow, UK. 9-13 November 2008

Published: 10 November 2008

Journal of the International AIDS Society 2008, I I (SuppI I):O8 doi:I0.II86/I758-2652-II-SI-O8

This abstract is available from: http://www.jiasociety.org/content/II/SI/O8

(c) 2008 Walker et al; licensee BioMed Central Ltd.

\section{Background}

The licensed lopinavir/r paediatric total daily dose is 460 $\mathrm{mg} / \mathrm{m} 2$ without, and $600 \mathrm{mg} / \mathrm{m} 2$ with concurrent NNRTIs. The $460 \mathrm{mg} / \mathrm{m} 2$ dose without NNRTIs was chosen in preference to $600 \mathrm{mg} / \mathrm{m} 2$ in a post-hoc drug-interaction analysis [1]. Excellent VL suppression was also reported $(79 \%<400 \mathrm{c} / \mathrm{ml}$ at $48 \mathrm{wks})$ but was based on the higher $600 \mathrm{mg} / \mathrm{m} 2$ dose. Thus, some paediatricians prefer this higher dose regardless of concomitant NNRTI therapy.

\section{Methods}

We calculated lopinavir/r doses $(\mathrm{mg} / \mathrm{m} 2)$ prescribed without NNRTIs in the UK/Irish CHIPS cohort from 20002007 , every time height/weight was measured. We investigated predictors of current dose, including sex; VL and $\mathrm{CD} 4 \%$ at the previous visit, current age, CDC stage, height/weight-for-age, calendar year, formulation, frequency and previous PI using mixed models with random effects for child and centre. We considered whether current lopinavir/r dose predicted the next VL being $<400 \mathrm{c} /$ $\mathrm{ml}$ using binomial mixed models.

\section{Summary of results}

$311 / 1,336(25 \%)$ children in CHIPS had ever taken lopinavir/r without NNRTIs, total 654 child-years. Median age at lopinavir/r initiation was 9.0 years (IQR 5.1-12.1). 684 doses were recorded in 299/311 children: $52 \%$ were syrup, $38 \%$ capsules and $10 \%$ tablets, with only $3 \%$ once (rather than twice) daily. Dose/m2 could be estimated 2,748 times in 278 children: few $(6 \%)$ were $>10 \%$ below the $460 \mathrm{mg} / \mathrm{m} 2$ target, and few $(9 \%)>10 \%$ above the 600 $\mathrm{mg} / \mathrm{m} 2$ target, with most $>410-<530 \mathrm{mg} / \mathrm{m} 2(46 \%)$ or $>530-<660 \mathrm{mg} / \mathrm{m} 2$ (39\%). In a multivariable model, doses were $17 \mathrm{mg} / \mathrm{m} 2$ [95\%CI 0-34] higher in children who had prior AIDS, $2 \mathrm{mg} / \mathrm{m} 2$ [0-3] higher for every $\log 10$ higher VL at the previous visit, $48 \mathrm{mg} / \mathrm{m} 2[38-58]$ higher with capsules/tablets vs. syrups, $22 \mathrm{mg} / \mathrm{m} 2$ [4-40] higher with twice- vs. once-daily dosing, $19 \mathrm{mg} / \mathrm{m} 2[15-$ $24]$ and $10 \mathrm{mg} / \mathrm{m} 2$ [6-14] higher for every one unit lower current weight- and height-for-age, respectively, and 9 $\mathrm{mg} / \mathrm{m} 2$ [5-14] higher for every year younger under $10(\mathrm{p}$ $<0.05$ ). Dosing varied widely by centre. Adjusting for age, there was no strong evidence that higher doses increased the chance of the next VL being $<400 \mathrm{c} / \mathrm{ml}(\mathrm{OR}=1.10$ $[0.96-1.25]$ per $50 \mathrm{mg} / \mathrm{m} 2$ higher, $\mathrm{p}=0.16)$ or $<50 \mathrm{c} / \mathrm{ml}$ $(\mathrm{OR}=0.82[0.73-0.91], \mathrm{p}<0.001)$. 


\section{Conclusion}

In summary, younger or stunted/wasted children or those with prior AIDS/higher VLs received higher doses. Doses were higher with capsules/tablets, likely reflecting overrather than under-dosing when solid formulations cannot achieve exact doses. However, we found no clear evidence that higher doses improved VL suppression.

\section{References}

I. Saez-Llorens X, et al:: Forty-eight-week evaluation of lopinavirl ritonavir, a new protease inhibitor, in human immunodeficiency virus-infected children. Pediatr Infect Dis J 2003, 22:216-224.

Publish with Bio Med Central and every scientist can read your work free of charge

"BioMed Central will be the most significant development for disseminating the results of biomedical research in our lifetime. " Sir Paul Nurse, Cancer Research UK

Your research papers will be:

- available free of charge to the entire biomedical community

- peer reviewed and published immediately upon acceptance

- cited in PubMed and archived on PubMed Central

- yours - you keep the copyright

Submit your manuscript here:

http://www.biomedcentral.com/info/publishing_adv.asp 